\title{
デジカメ航空写真による中小河川の地形データ 作成と河道計画への適用可能性
}

POSSIBILITY OF APPLICATION OF PHOTOGRAMMETRY AND RIVER CHANNEL PLANNING USING DIGITAL AERIAL CAMERAS FOR MIDDLE AND SMALL RIVER

\author{
大石哲也 1 ・萱場祐一 1 ・加瀬瑛斗 $2 \cdot$ 渡辺敏 $3 \cdot$ 高岡広樹 1 \\ Tetsuya OOISHI, Yuichi KAYABA, Eito KASE, Satoshi YATANABE and Hiroki TAKAOKA \\ 1正会員 工博 （独）土木研究所 水環境研究グループ 自然共生研究センター（テ501-6021 岐阜 \\ 県各務原市川島笠田町官有地無番地) \\ 2正会員 工修 株ウエスコ 設計課（干651-0092 神戸市中央区生田町 2-2-2） \\ 3正会員 工博 株ウエスコ 環境計画部 水環境チーム（同上）
}

\begin{abstract}
The purpose of this paper is to suggest possibility of the application of the middle and small river channel planning by photogrammetry with digital aerial cameras. We have obtained the spots of surface elevation both topographical survey in river with VRS-GPS or Total Station and photogrammetry with digital aerial camera (UltraCamX), and evaluated numerical differences of longitudinal water level by 1D-flow analysis using those spots.

As a result, the difference of cross section area(per survey line) between topographical survey and photogrammetry(high-resolution $5 \mathrm{~cm} /$ pixel)is $0.8 \mathrm{~m}^{2}\left(0.03 \mathrm{~m}^{2} / \mathrm{m}\right)$. The water level caluculation results were at almost same between using topographical survey dates and using photogrammetry(low-resolution $10 \mathrm{~cm} /$ pixel) edited by human. However, the edited photogrammetry required much processing time although it was accurate. We concluded that it is important to enhance accuracy by using a near-infrared photograph can identify the vegetation area and, as much as possible, to automate the measurements of surface elevation for the river channel planning.
\end{abstract}

Key Words : river management, photogrammetry, DEM, DSM, river planning

\section{1.はじめに}

日本の河川延長は，一級河川で約 $88,000 \mathrm{~km} ，$ 二級河川 で約36,000kmに及び，このうち，都道府県が管理する河 川（以下，ここでは総称して「中小河川」という）は， 約77,000kmである. 国土交通省が管理する大河川と比較 して，中小河川で河道計画（治水計画）を策定する際に 問題となるのは，河道計画・設計を行うための基本的な 情報（河道縦横断測量，水位・流量観測等）が乏しい点 があげられる1)。これには，財政面上の厳しさと同時に， 土地制約の条件も重なり，十分な実行ができないことが 一因と思われる.

現状での中小河川の河道計画・設計においては，横 断面形状の測量後に, 一次元不等流計算により水位計算 を行い, 各断面における流下能力判定をしたうえで, 改 修目標流量を流下させるために必要な断面設定を行って いくことが推奨されている.

現況での横断面形状の取得に際しては，概略設計時 に約 $100 \mathrm{~m}$ 間隔で, 詳細設計時に約 $20 \mathrm{~m}$ 間隔で 2 度に分 けて現地測量を行う場合が多い.この問題点として, 概 略設計時には不等流計算に必要な地形情報が十分に得ら
れないことや，現地測量は，精度は良いものの取得に時 間がかかるだけでなく，面的情報でないため，基盤情報 の 2 次的活用が困難である点などがあげられる.

これに対して，レーザ・プロファイラ（以下 LP とい う）は，近年，多くの砂防・河川で利用され，管理に生 かすべく研究がなされている 1) 2) 3)．LPデータは，ラ ンダムにレーザパルスを照射することで，表層高

(DSM: Degital Surface Model) , 地上高（DEM: Digital Elevation Model）を広範囲に，面的に取得できるという 利点を持つ. しかし，ランダムにレーザを照射するため， 河岸法肩・法尻といった端点（地形変化点）の取得がで きないほか, 水面下の河床高が取得できないという問題 点も指摘もされている ${ }^{4}$.

この他, 高精度カメラを利用し, 航空撮影された写 真をスキャナによりデジタル化し, 立体視による DSM, DEM を得る技術も進展してきている 5) 。 . この技術を利 用した研究は，とくに欧米を中心に盛んであり5，例え ば，水面下の河床高を画像処理技術によって把握》，水 食による複雑地形のモデル化と複数の画像処理方法の違 いによる精度検証 ${ }^{8}$ など，地形変化を定量的に把握する 取り組みがなされている.さらに，2000 年代中期から 
高精度デジタルカメラを航空機に搭載し, 撮影されたデ 一タを直接に処理しており，スキャナによる読み込み誤 差を無くすことで精度向上, 処理時間の短縮化を計って いる.この利用例として，例えば，都市域のグランドマ ップとして利用する取り組みも見られる ${ }^{9}$ 。このように 最新のカメラ, 画像処理技術を利用寸ることで, LP で 指摘されているような問題点を解消でき, 地形形状取得 の精度向上に寄与できる可能性が高い.

以上を背景とし, 本研究では, 河道計画時に必要と なる横断面形状の取得に関して, 現地測量データ, デジ カメ航空写真を図化処理することで横断面形状を取得し， このデータを元に治水安全度評価（一次元不等流計算） を行った場合に, 各の手法でどの程度の誤差が生じるか について検討した. また, 本報でとりあげたデジカメ航 空写真による技術について, 精度の面, 時間的なコスト の面など河川管理に利用していくうえでの適用可能性と 課題について考察を行った.

\section{2. 検討方法}

\section{（1）対象河川と対象区間}

対象河川の小里川 (岐阜県) は，庄内川の支川で，流 路延長 $24.6 \mathrm{~km}$, 流域面積 $99.2 \mathrm{~km}^{2}$ である. 対象区間は, 恵那市山岡町付近の $6.8 \mathrm{~km}-7.7 \mathrm{~km}$ の区間とした（図-1）。 対象区間の特徴としては，単断面の直線区間，蛇行区間， 巨碩による砂州の堆積区間, ツルヨシを中心とする植物 繁茂の区間，護岸上の樹木が河床面をオーバーハングし ている区間など，中小河川でよく見られる様々な河川景 観を短区間で有している点があげられる，なお，当該区 間の河床勾配は約 1/250である.

\section{（2）横断面形状の取得と図化処理方法}

河道の横断面形状の取得は, 現地測量とデジカメ航空 写真から得られた画像を図化処理することによって得た

（図-2）。撮影は，地上高ができるだけ撮影できるよう に植物がある程度枯れた平成 22 年 12 月に行った。 また, 現地測量は平成 22 年 12 月と平成 23 年 6 月に行った.

なお，本報では，岐阜県が平成 16 年に計測した LPに よる DEM データについても図化処理し, 参考までに比 較対象とした．レーザ計測密度については，国土交通省 河川局による指針 ${ }^{10}$ ) で $2 \mathrm{~m}$ ピッチを最低条件としてお り, ここでは $2 \mathrm{~m}$ ピッチでの比較とした.

\section{(1)現地測量 : 現地での測量点の取得}

中小河川の場合，大河川の直轄区間のように河川に 沿って距離杭を設置している個所が少なく, 既知点での 基準点を設定することが困難なケースが多い，そこで， 現地での測量は，携帯端末の利用により数秒で精度良く 座標が取得可能な VRS-GPS（Trimble 5800），もしくは, 衛星からの情報取得が困難な場所（時間により衛星角度

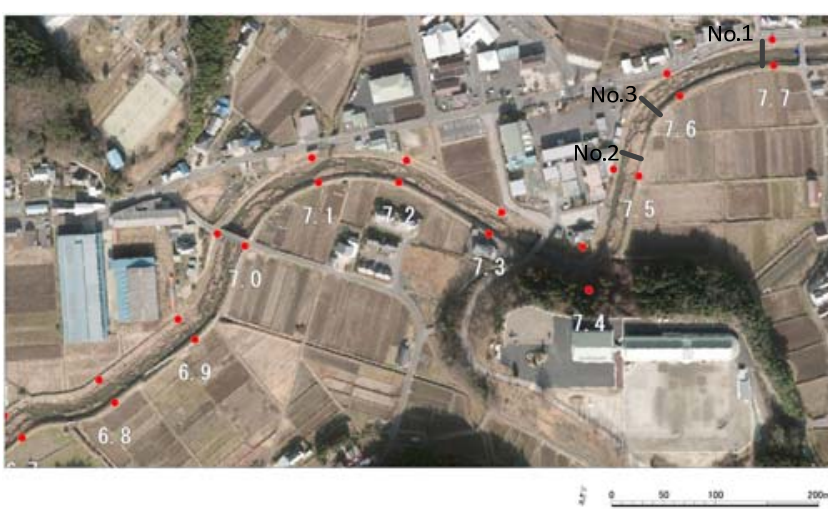

図-1 対象区間の距離標と横断面形状の測線 No

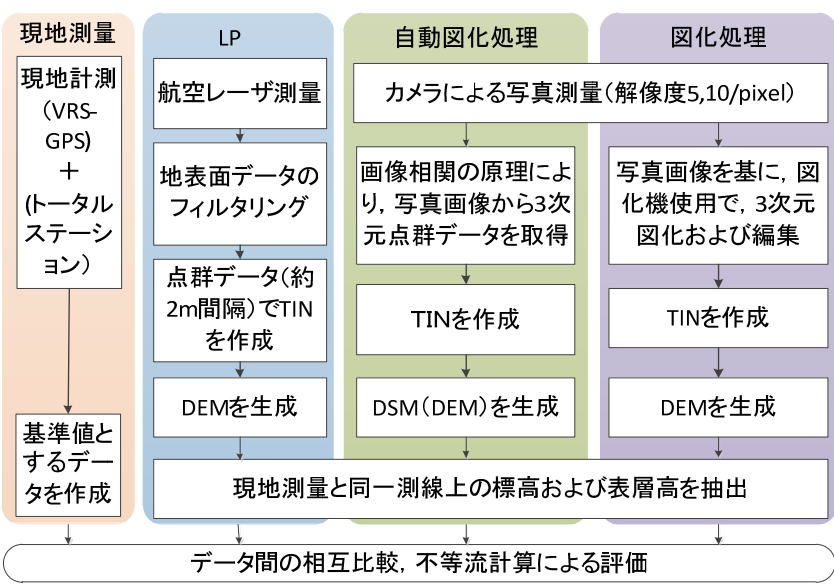

図-2＼cjkstart使用データと図化処理および評価の流れ

が悪い場合や上部空間の遮蔽が大きい場合）にも計測が 可能なトータルステーション（Trimble S3）のいずれか を利用した。ここで扱ったトータルステーションは，測 量者が手にするプリズムを自動追尾できるシステムであ り，1名から測量が可能である。

現地計測の作業内容としては。まず，前処理として GIS（Esri 社製 Arc GIS9.0）に小里川の基図を読み込ん だ後，対象区間に対して縦断方向に $20 \mathrm{~m}$ 間隔で平常時 の流向に対して直角になるように横断測線（ポリライン） を引き，このポリラインをコントローラー（VRS-GPS とトータルステーションの双方に対応）へ格納した. 次 に，現地にて，VRS-GPS 単独で測量を行うか, 任意の 点でトータルステーション設置点の座標を VRS-GPS に よって計測し，トータルステーションの設置座標を定め て計測を行った。いずれの場合も測点の取得は，コント ローラーに格納したポリラインを参考に行った.

\section{(2)デジカメ航空写真による測量点の取得}

使用した高精度デジカメカメラは，ベクセル社製 UltraCamX（UCX）である. 本機は，8個のカメラヘッド があり，このうち 4 つは解像度の高いモノクロ画像，残 り 4 つにより, カラー画像 (RGB) と近赤外画像 (NIR) を取得できる．また，本システムは，LP 同様に撮影高 度により精度が異なる．ここでは，撮影高度を変え（才 一バーラップ率は 60\%)，解像度が 1pixel あたり $5 \mathrm{~cm}$ お 
よび10cmの2ケースについて撮影を行った.

撮影後は，処理方法を変えて画像上の座標を読久取っ た．具体的には，画像相関技術（図-3）を用いて，隣接 画像の視差を利用し自動的に表層高（DSM）を抽出す 万方法 (独：Inpho 社製 MATCH-T) (以下, 自動図化 処理という）と，画像を立体視することで任意の地上高

（DEM）を取り出寸方法（以下，図化処理という）か ら，点群データを取得した。

\section{(3)TIN データから測線図の作成}

現地測量ならびにデジカメ航空写真から得られた点群 データは, GIS を用いて, TIN (Triangulated Irregular Network）処理し，3次元地形図モデルに変換した．TIN で補完された三角形網を点群データ化し，現地測量で得 られた測線と同一測線上の地上高および表層高を抽出し た.

\section{（3）計算方法の概要}

一次元不等流計算はヤマソフトプランニング（有）

「奔流」により行った．流量については，小里川の暫定 計画流量（1/2 確率規模の流量）とした。下流端の境界 条件は，下流端断面の等流水深を与えた。粗度係数は, 岐阜県が小里川での水位計算で用いた值（0.03）とした. 計算ケースを表-1 に示す。 ケース a では，現地測量で 得られたデータを用いており，測線間隔を $20 \mathrm{~m}, 40 \mathrm{~m}, 80 \mathrm{~m}$ と変化させ，内挿間隔の違いが計算精度に与える影響に ついて検討を試みた。

ケース b,c は，いずれもデジカメ航空写真から得られ るデータであり, 処理方法の違いが計算精度に与える影 響について検討を試みた。なお，横断面形状は解像度 $10 \mathrm{~cm}$ のデータを利用し, 縦断方向の内挿間隔は $20 \mathrm{~m}$ と した。 また，ケース bについては，自動図化処理に伴う 端点処理の不具合を避けるため，本報では護岸部分のみ 図化データを併用した（以下，これを自動図化処理 (hybrid) と言う) .

\section{（4）検討結果の比較方法}

\section{(1)横断面形状結果の比較}

横断面形状の比較は，定性的な概観に加えて，定量的 な方法により行った。 具体的には，対象区間の任意の測 線で，測線図を描いたのちに現地測量データと対象測線 の間にできる誤差を断面積として，絶対量と測線あたり の誤差（断面積測線長さ）を比較した．対象とした横 断測線は，水域部に巨石などの凹凸の無い測線（No.1）, 片岸に高水敷（テラス）が発達した測線（No.2），水域 部に巨石などの凹凸があり砂州上に植物が旺盛に成長し ている測線（No.3）とした（写真-1，図-1参照）。

\section{(2)一次元不等流計算結果の比較}

計算結果の比較は，水面形の概観に加えて，横断面形 状の比較と同様に，現地測量地形に基づいて計算された 水位を真值とし，各横断測線上で真值との水位差を絶対 表-1＼cjkstart計算ケース

\begin{tabular}{|c|c|c|}
\hline ケース & 地形データ & 備考 \\
\hline $\mathrm{a}-1$ & $\begin{array}{c}\text { 現地測量 } \\
\text { (縦断 } 20 \mathrm{~m} \text { 間隔) }\end{array}$ & \multirow{3}{*}{ DEMデータ } \\
\hline$a-2$ & $\begin{array}{c}\text { 現地測量 } \\
\text { (縦断 } 40 \mathrm{~m} \text { 間隔) }\end{array}$ & \\
\hline$a-3$ & $\begin{array}{c}\text { 現地測量 } \\
\text { (縦断 } 80 \mathrm{~m} \text { 間隔) }\end{array}$ & \\
\hline b & $\begin{array}{c}\text { 自動図化処理 } \\
\text { (hybrid) }\end{array}$ & $\begin{array}{l}\text { 主に DSMデータ（自動）像護岸は図化を使用, 解像 } \\
\text { 度は } 10 \mathrm{~cm} \\
\text { 内挿間隔は } 20 \mathrm{~m}\end{array}$ \\
\hline c & 図化処理 & $\begin{array}{l}\text { DEMデータ (人的) } \\
\text { 解像度は } 10 \mathrm{~cm} \\
\text { 内挿間隔は } 20 \mathrm{~m}\end{array}$ \\
\hline
\end{tabular}

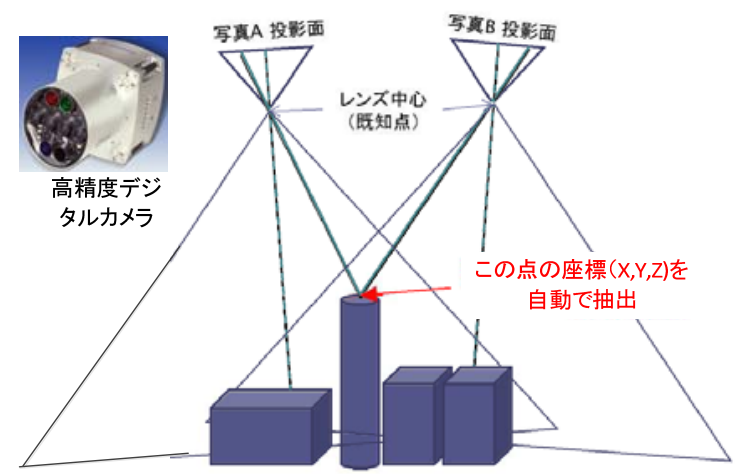

図-3 画像相関の原理

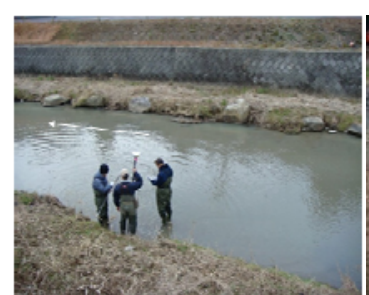

No. 1

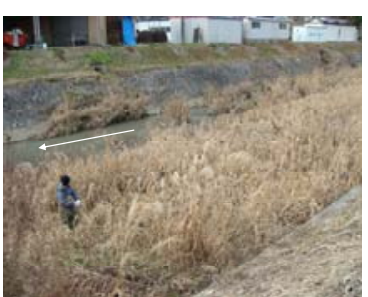

No. 2

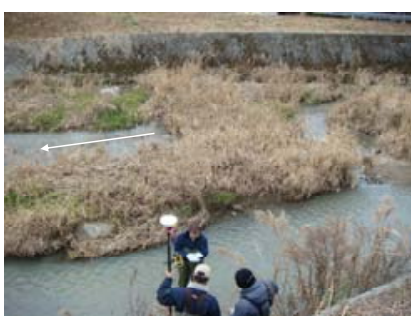

No. 3

写真-1 測量地点の状況

值で評価した.

\section{(3)図化処理に要する時間の比較}

河川管理の適用を考えると，単に精度がよいという理 由だけでなく，いかに経済的で実用性があるかも加味し ておく必要がある。そこで，(1)の作業で TIN モデルを 作成し，横断測線図が得られるまでの処理時間について， 処理方法ごとに計測した。 


\section{3. 結果と考察}

\section{（1）横断面形状の比較}

図-4 に No.1 No.3 の横断面形状を示す. 横断面形状 は, 現地実測と比較し, 図化処理で解像度 $5 \mathrm{~cm}$ （以下， 図化処理（5cm）とし，他もこの標記に従う），図化処 理 $(10 \mathrm{~cm})$, 自動図化処理 $(5 \mathrm{~cm})$, 自動図化処理 （10cm），LP データの順に誤差が大きかった。現地測 量と誤差があった部分の特徵としては，高水敷や巨礫周 辺に生育するツルヨシを中心とする植物が繁茂した筒所

（例えば，No.1：起点 $(0 \mathrm{~m})$ から 6-8m, No.2：起点か ら 7-15m，No.3：起点から 11-15m）で，自動図化処理と 現地測量との間に 10-20cm の差が表れていた．また，水 深については， $10 \mathrm{~cm}$ を下回る箇所では，解像度に係わ らず自動図化処理，図化処理ともに現地測量との整合性 が高かった（例えば，No.1：起点から 9-18m，No.2：起 点から 15-20m, No.3：起点加 8-10m) .

しかしながら, No.2 の起点から 21-23m 付近にみられ る水深 $30 \mathrm{~cm}$ となると図化処理 $(5 \mathrm{~cm})$ でも, 約 $10 \mathrm{~cm}$ の 水位の誤差が生じていた。写真解像度がよい場合，これ までの研究から $1 \mathrm{~m}$ 程度の水深であれば，河床高まで計 測が可能であり ${ }^{11)}$ ，筆者らの経験からも水深 $1 \mathrm{~m}$ であれ ば河床高を読み取れている，これらから鑑みるに，当日 は河床が確認できないほど水が濁っており，このことが 精度に関係していたものと考えられる。

表-2 に現地測量と各横断面形状の間に生ずる断面積 から求められる誤差量および測線あたりの単位誤差を示 す. No.1のように，水域部に巨石などの凹凸の無い測線 では，誤差も他の断面（No.2,3）と比較して小さい， と くに，図化処理 $(5 \mathrm{~cm})$ では，誤差量が $0.8 \mathrm{~m}^{2}$ と他の断 面および他の処理方法と比較し最も小さかった．さらに, 測線あたりの単位誤差もわずか $3 \mathrm{~cm}$ であった。 また， No.1 の図化処理 $(5 \mathrm{~cm})$, 図化処理 $(10 \mathrm{~cm})$ の誤差は, No2,3 のそれらと比較しても誤差量, 単位誤差が最も小 さく, 精度が良かった。

No.2のように，片岸に高水敷（テラス）が発達した測 線では，いずれの処理方法でも No.1 の誤差よりも大き くなった．撮影は植物がある程度枯れた時期に行ったも のの，現状の処理方法では地上高の取得が困難であった と推察される.

No.3のように，水域部に巨石などの凹凸があり砂州上 に植物が旺盛に成長している測線では，他の測線と比較 し誤差が大きい傾向にあった。ささら，No.1，No.2 の図 化処理 $(5 \mathrm{~cm}, 10 \mathrm{~cm})$ では，解像度の違いによって誤差 に約 2 倍の開きがあったが，No.3において両者の間には 約 1.3 倍程度の開きしかなかった. No.3のように凹凸が 激しく, 河道内に密生した植物が多い場合は, 地盤高の 取得が困難となり，凹凸変曲点での端点を正確に取得し 難いため，解像度の差ほど，結果に差が現われないもの と考えられる.
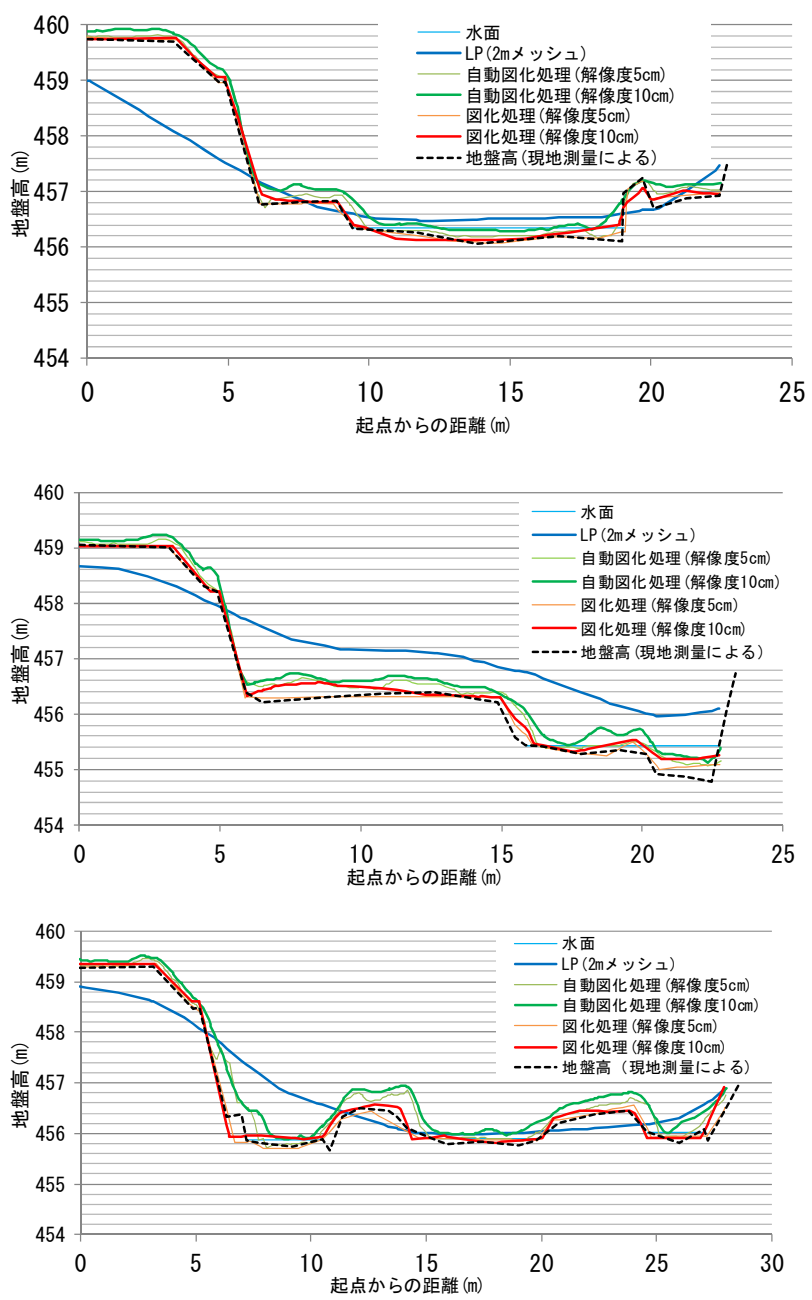

図-4 横断面形状（上 No.1, 中 No.2, 下 No.3）

表-2 横断面形状に生ずる現地測量との誤差量 $\left(\mathrm{m}^{2}\right)$ と 測線あたりの単位誤差(m)

\begin{tabular}{lc|rrrrr|r} 
& & LP & 自動(10) & 自動(5) & 図化(10) & 図化(5) & 測線長 $(\mathrm{m})$ \\
\hline \hline No.1 & $\mathrm{m}^{2}$ & 11.6 & 4.9 & 2.3 & 1.8 & 0.8 & \\
& $\mathrm{~m}^{2} / \mathrm{m}$ & 0.52 & 0.22 & 0.10 & 0.08 & 0.03 & 22.4 \\
\hline No.2 & $\mathrm{m}^{2}$ & 18.8 & 6.4 & 4.0 & 2.8 & 1.4 & \\
& $\mathrm{~m}^{2} / \mathrm{m}$ & 0.83 & 0.28 & 0.18 & 0.12 & 0.06 & 22.7 \\
\hline No.3 & $\mathrm{m}^{2}$ & 12.1 & 9.0 & 5.3 & 2.8 & 2.2 & \\
& $\mathrm{~m}^{2} / \mathrm{m}$ & 0.44 & 0.32 & 0.19 & 0.10 & 0.08 & 27.8
\end{tabular}

LP データについては，全体的に誤差が大きかったこ とや，変化点の明膫さに欠けていた，当該河川のように， 川幅が小さい場合は，2m メッシュの解像度だと実際の 形状に対しての誤差割合が大きなってしまい，河道計画 への適用が難しいと考えられる。ただし，LP データの 場合も，データ密度を向上させれば，本報で示寸自動図 化処理と同等までの精度が得られるものと思われる.

\section{（2）不等流計算結果の比較}

図-5 に現地測量，図化処理，自動図化処理（hybrid） によって得られた縦断方向の水位分布を示した.

内捰間隔を変えたケース a でみると，現地測量（内挿 40m）は，現地測量（内挿 20m）と6.8〜 7.4km までほぼ 


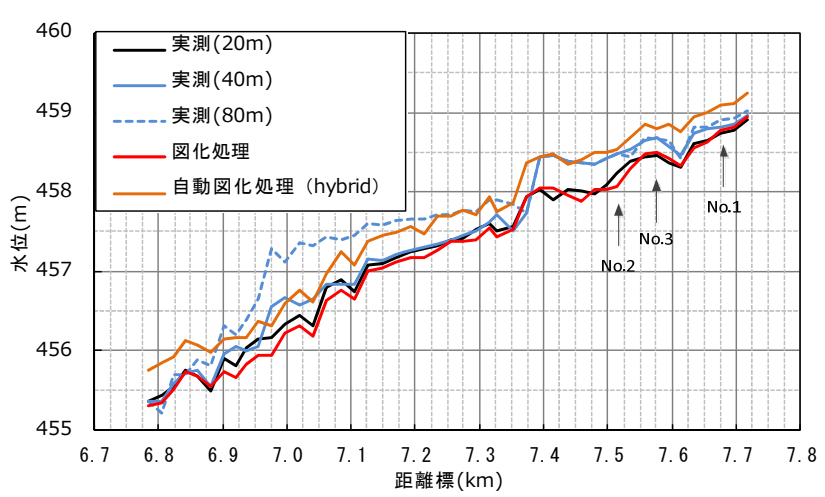

図-5 不等流計算による水位計算結果

同様な傾向を示したが， $7.4 \mathrm{~km}$ 付近で約 $0.5 \mathrm{~m}$ の水位上 昇が見られた。 また，現地測量（内挿 80m）では，下流 区間で約 $1 \mathrm{~m}$ の上昇がみられ，7.4km 付近では現地測量 （内挿 $40 \mathrm{~m}$ ）でみられた現象と同じく, 約 $0.5 \mathrm{~m}$ の水位 上昇があった. $7.4 \mathrm{~km}$ 付近は，区間の中で最も屈曲する 蛇行部にあたり（図-1 参照），内挿した間隔が不十分 で地形条件をうまく再現できず，水位上昇の影響が上流 方向へ波及してしまったため, 精度が悪くなったものと 考えられる.

写真データの処理方法を変えたケース b,c で比較する と, ケース b の自動図化処理（hybrid）は, 現地測量に 比べて, ほぼ全区間で水位が約 $0.5 \mathrm{~m}$ 上昇した. 自動図 化処理（hybrid）は，地上高がなるべく計れるように冬 場に計測したものの図-4 で示したように植物の草丈分 だけ誤差が生じてしまったようである.

ケース c の図化処理は，全体的には現地測量（内挿 20m）とほぼ同じ水面形を示した. しかし，6.9-7.1 km 付 近では両者の間で 0.1-0.2m の差が生じていた。この区間 は, 低水路内の地形口凸が複雑で植物も旺盛に繁茂して いた箇所であった. このため, 現地測量の計測誤差や図 -4でも見られたように, 裸地域が少ないために図化処 理精度が低下したことが要因となり，不等流計算での誤 差に繋がったものと考えられる.

表-3 に一断面あたりの計算水位について, 現地測量 (20m 間隔) に対しての誤差を示した. 定量的な評価か らも図化処理の精度が $0.12 \mathrm{~m}$ と最も良かった. 以降は, 現地測量（内插 40m），自動図化処理（hybrid）,現地測 量（内挿 80m）の順に精度が悪くなった.

\section{（3） 作成時間の比較}

デジカメ航空写真は, 図化処理 (図-6, 図-2 参照) を行った後に必要な測線を得る作業手順となる．そこで， 各処理を経て測線を得るまでにかかる作業時間を表-4 に示した。結果として, 自動図化処理 $(10 \mathrm{~cm})$ が最も 作業時間が短く $1.5 \mathrm{~h} / \mathrm{km}^{2}$ であった. また, 自動図化処理

(5cm) だと解像度 $10 \mathrm{~cm}$ のときよりも約 4 倍の時間が かかった.さらに, 図化処理は, 自動図化処理と比較し て，いずれも 700 倍以上も時間を有していた.

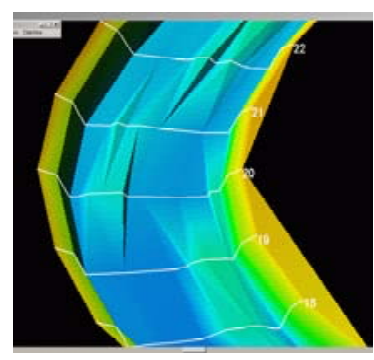

現地測量

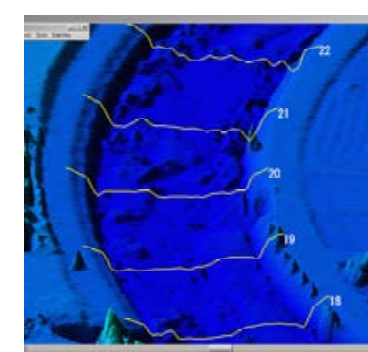

自動図化処理

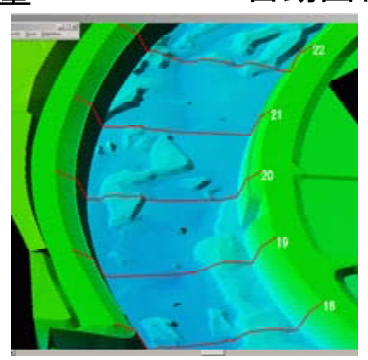

(人的)図化処理

図-6 図化処理 (TIN) モデルと横断測線図

表-3 一断面あたりの計算水位の誤差

\begin{tabular}{|c|c|c|}
\hline ケース名 & 使用した地形データ & $\begin{array}{l}\text { 計算水位の } \\
\text { 誤差 }(\mathrm{m})\end{array}$ \\
\hline $\mathrm{a}-1$ & 現地測量 (20m間隔) & - \\
\hline $\mathrm{a}-2$ & 現地測量 (40m 間隔) & 0.21 \\
\hline $\mathrm{a}-3$ & 現地測量 (80m 間隔) & 0.45 \\
\hline $\mathrm{b}$ & 自動図化処理 (hybrid) & 0.37 \\
\hline $\mathrm{c}$ & 図化処理 & 0.12 \\
\hline
\end{tabular}

表-4 測線を得るまでの作業時間の比較

\begin{tabular}{c|cccc} 
& デDSM(10) & デDSM(5) & デ図化(10) & デ図化(5) \\
\hline \hline 作成時間 & $1.5 \mathrm{~h} / \mathrm{km}^{2}$ & $6.4 \mathrm{~h} / \mathrm{km}^{2}$ & $1.000 \mathrm{~h} / \mathrm{km}^{2}$ & $6.000 \mathrm{~h} / \mathrm{km}^{2}$
\end{tabular}

作成時間| $1.5 \mathrm{~h} / \mathrm{km}^{2} \quad 6.4 \mathrm{~h} / \mathrm{km}^{2} \quad 1,000 \mathrm{~h} / \mathrm{km}^{2} \quad 6,000 \mathrm{~h} / \mathrm{km}^{2}$

以上の傾向は, 精度評価で得られた結果と逆の傾向で あった. 自動図化処理, 図化処理ともに解像度が 2 倍に なると，精度は 1.6-1.8倍に良くなるものの，作業時間は 4〜6 倍に増えていた. 寸なわち, 解像度, 点群密度, 撮影高度といった精度を 2 倍あげようとすると, 面積あ たりの解像度（pixel）は４倍となるため，これがそのま ま作業時間に反映されたものと考えられる.

\section{4. デジカメ航空写真の中小河川管理への適用可 能性と課題}

デジカメ航空写真は，1 度の飛行で景観，植生（近赤 外），3 次元地形モデル（DSM, DEM）の情報を取得可能で, 後から必要な個所（断面）だけ座標を取得できるという 特徴を持つ.ただし，河道設計一の利用に際しては，人 的作業を多く伴う図化処理は最小限に抑えたうえで，画 像相関によるマッチング技術（自動図化処理）の併用, さらなる処理技術の向上の方向性を求めることが妥当と 考えられる. 
図-4 では，現地測量との差異や表-3 に示すように， 内挿間隔を広げた場合の水位誤差について検討し，測線 上での誤差量について検討を行った. 結果として，現地 測量 $(20 \mathrm{~m})$ と図化処理の間で，計算結果に高い整合性 が見られた. しかしながら，現地測量を 3 次元地形デー タ化すると，実河川とは異なる河道形状となってしまっ ており（図-6），例えば，微地形空間を利用する生物生 息場の地形解析一の適用可能性が低くなるだろう.

また，表-3 に示した水位計算結果では，結果的に内 挿 40m 間隔での計算結果の方が自動図化処理よりも優れ ていたが，内挿間隔が広くなると実務的な面で設計が困 難となる問題も生じる. 自動図化処理での結果は, 植生 域を十分に考慮できていなかったことが主な要因であり, この解消として，近赤外線で植生域を判別し，平均的な 草丈から水位上昇時に生じる倒伏分 ${ }^{12)}$ 差し引けば，比 較的容易に計算精度向上に繋がるものと考えられる。

デジカメ航空写真は, 河道内の状況を面的に把握でき, GIS 等にも瞬時に搭載可能なため, 従前の手法と比較し ても，より視覚的，高精度に河道の地形，植生の状況の 変化を把握できる可能性がある. 以上のような方向性を もつて課題を解決してゆけば，基礎情報が不足している 中小河川においても，効率よく地形データが作成可能で, 現場で要求される精度を相当に満たす便利なツールとな ろう.

\section{5. まとめ}

本研究では河道計画時に必要となる横断面形状の取得 に関して，現地測量データ，デジカメ航空写真を図化処 理することで横断面形状を取得し，このデータを元に治 水安全度評価（一次元不等流計算）を行った場合に，各 の手法でどの程度の誤差が生じるかについて検討した. また，本報でとりあげたデジカメ航空写真による技術に ついて，精度の面，時間的なコストの面など河川管理に 利用していくうえでの適用可能性と課題について考察を 行った.

対象とした小里川での検討結果として，以下の結論が 得られた。

1) 現地測量データと人的な図化処理データ（解像度 5cm/pixel）とにできる横断面形状の差異は，断面積にし て $0.8 \mathrm{~m}^{2}$ ，測線の単位誤差は $0.03 \mathrm{~m}^{2} / \mathrm{m}$ であった。

2) 一次元不等流計算結果（横断測線の内挿間隔は 20m) から，現地測量データと図化処理（解像度 $10 \mathrm{~cm} / \mathrm{pixel}$ ) での縦断水位は概ね一致した。

3) 人的な図化処理は精度はよいものの，作成時間がかか るため，河道計画一適用する場合，現実的には，自動図 化処理の精度向上（近赤外線写真の利用により植生域の 処理精度を向上）を図ることが重要であることを示した。
謝辞 : 本研究を進めるにあたり，岐阜県県土整備部河川 課長 堂薗俊多 氏を始め, 河川課の皆様にはデータの 提供，県河川の管理状況の実態について惜しみないご協 力を頂いた．とくに，前自然共生研究センター 交流研 究員上野公彦（現 岐阜県県土整備部河川課）氏には, 現地調査，資料収集，県河川の管理状況について，ご協 カ・ご指導いただいた．また，(株)ウエスコ 赤井晋也氏 にはデジカメ航空写真に関しての有用な助言をいただい た、末筆ながら，ここに感謝の意を記します。

\section{参考文献}

1) 藤田光一: 中小河川の治水安全度を早急に把握せよ（特集 1 今までにない自然災害に立ち向かう）, 国土技術政策総合研 究所,国総研アニュアルレポート,vol.5, pp.12-15, 2006.

2) 林慎一郎，水野正樹，小山内信智，堀内成郎，杉崎敏仁 : 砂 防航測レーザプロファイラ計測データ管理システムの構築と 活用，砂防学会研究発表会概要集，pp.200-201,2011..5.

3) 国土交通省河川局，国土交通省国土技術政策総合研究所水害 研究室，航空レーザ測量を活用した治水安全度評価， http:/www.nilim.go.jp/lab/rcg/newhp/seika.files/p/index.htm

4) 寺中愛瑛, 小林一郎, 宮下征士 : 都市内中小河川管理への 点群データの活用, 平成21年度土木学会西部支部研究発表会, 2010.3.

5)林舟, 小口高: 地形学における写真測量法の応用:欧米の事例 を中心に,地學雜誌, vol.111(1),pp. 1-15, 2002.2.

6) Lane, S.N.: The Measurement of River Channel Morphology Using Digital Photogrammetry, The Photogrammetric Record, vol.16(96)(937-961), 2000.10 .

7) Westaway, R.M., S.N. Lane, D.M. Hicks: The development of an automated conection procedure for digital photogrammetry for the study of wide, shallow, gravel-bed rivers, Earth Surface Processes and Landforms, vol.25(2), pp. 209-226, 2000.2.

8) Lane, S.N., T.D. Jaames, M.D. Crowell: Application of digital photogrammetry to complex topography for geomorphological research, The Photogrammetric Record, vol.16(95), pp. 793-821, 2000.4.

9) Brüßhaber, C., A.M. Trosseta, T. Buchera: Possibilities and constraints in the use of very high spatial resolution UltraCamX airbome imagery and Digital Surface Models for classification in densely built-up areas - a case study of Berlin, Earth Resources and Environmental Remote Sensing/GIS Applications. Edited by Michel, Ulrich; Civco, Daniel L., vol.7831, pp. 783115(1-12), 2010.

10) 国土交通省河川局 : 航空レーザ測量による河道及び流域の 三次元電子地図作成指針（案）,2005.6

11) 傅田正利，時岡利和，天野邦彦: レーザプロファイラ及び空 中写真を用いた河川中流域の河床高推定手法の開発, 河川技 術論文集, vol.12,pp.145-150, 2006.6

12) 服部敦: 流れによる変形を考慮した高茎草本植物の抵抗則, 土木学会論文集, vol.782/I(70),pp. 65-80, 2005.2.

(2011. 9. 30 受付) 